\begin{tabular}{ccc}
\hline & International Journal of Engineering \& Technology, 7 (3.9) (2018) 100-103 \\
SPC & Website: $w$ ww.sciencepubco.com/index.php/IJET \\
\hline
\end{tabular}

\title{
A case study on quality of services for bus performance in Putrajaya, Malaysia
}

\author{
Shuhairy Norhisham ${ }^{1}$, Amiruddin Ismail ${ }^{2}$, Muhamad Nazri Borhan ${ }^{2}$, Herda Yati Katman ${ }^{1}$, \\ Nor Hazwani Nor Khalid ${ }^{1}$, Nur'atiah Zaini ${ }^{3}$ \\ ${ }^{1}$ Department of Civil Engineering, College of Engineering, Universiti Tenaga Nasional, Malaysia \\ ${ }^{2}$ Department of Civil and Structural Engineering, Faculty of Engineering and Built Environment, \\ Universiti Kebangsaan Malaysia, Malaysia \\ *Corresponding author E-mail: shuhairy@uniten.edu.my
}

\begin{abstract}
In accessing quality bus service in Putrajaya, 6 attributes were chosen as suggested by experts and summary review of four guidelines in bus transit manual from New Zealand, United Kingdom, United State and Australia. Six (6) attributes was identified, namely Services Hours, Load Factor for passenger, Comparison Car and Bus Travel, Frequency of Bus, on-time Performance and Coverage Services Area was conducted to check the quality of services for bus in Putrajaya. As a finding hours of services, passenger load factor and transit automotive comparison travel time was good with A and B rating of quality of services. Meanwhile, service coverage area and on time performance was factor needed to improve immediately. Overall it was found that the bus services in Putrajaya, according to the accessing method by Transit Capacity and Quality of Service Manual (TCQSM), was considered as moderate.
\end{abstract}

Keywords: Quality of Services; Bus performance; Bus Rating.

\section{Introduction}

This research is a case study paper. The aim of this paper analyse the quality of services (Q.O.S.) for bus in Putrajaya.

Putrajaya, a well-planned city, located south of Kuala Lumpur, between stain Putrajaya of Selangor and Negeri Sembilan. It's serving as federal administrative centre of Malaysia and was shifted in 1999 from Kuala Lumpur. As increasing number of more government offices transfer to Putrajaya. The increasing of road users also become an issues. In 2007, the population of Putrajaya was estimated to be over 30,000, which comprised mainly government servants [4] [2]. The number of personal vehicle is also increasing with the increase in Putrajaya's population. Promoting to use bus services in one of an agenda to solve the congestion problem.

It is important and need to have assessment on quality of services for bus in Putrajaya [11]. The study will chose from suitable attribute. The objectives of this research is to determine the quality of service (Q.O.S.) of bus services with case study in Putrajaya. This research only focuses on users from outside Putrajaya to Putrajaya. The location of survey works will be at Precinct 1 Park and ride Terminal. From 13 routes in Putrajaya, 6 bus route was chosen to analyse in putrajaya Percint 1 from park and ride terminal until Government complex A, B, C, D, and E in Precinct 1 include all bus stop along the route. Bus is the only mode of transportation to be studied.

\section{Methodology}

2.1. Service hours
Services hours or services span is a duration hours of bus services in those area. The span services was measure the bus services in hour per day. Weekend services is most important the key of success for accessing services hour.

This may be part of satisfactory of users when the facilities can provided in all day within the week. Secondly consideration if the services provide early morning until late night. The result data then was compared with those given in Table 1 to identify the quality of services:

\begin{tabular}{lllllll}
\multicolumn{7}{c}{ Table 1: Q.O.S. for Operation Services Hours } \\
\hline Q.O.S & A & B & C & D & E & F \\
\hline Service & More & 15 & 12 to & 7 to & 4 to & Less \\
(Hours) & 18 & to18 & 14 & 11 & 6 & 4 \\
\hline
\end{tabular}

\subsection{Passenger load}

Passenger load factor is mostly related to comfort and convenience of the transit facilities. From the passengers perspective, passengers load reflect the comfort level when the user step in the bus. This comfortable will assess the availability to find a seats and in overall crowding levels within the vehicles. As for transit operators perspective, a poor LOS may indicate need to increase the frequency of the services [14]. The peak hours under study were as follows: Morning-Peak: 7.30morning - 9.30morning , afternoo-Peak : 12.00afternoon - 2.00afternoon, evening-Peak : 4.30evening 6.30Evening.

The data were taking follow the about timing. The date were taken by weekday and weekend. After each bus stop passenger get in and out of the bus was recorded and calculated using this equation below:

Load Factor $=$ number of Passengers $/$ number of Seats $x 100 \%$ 
The load factor was check with Table 2 to get the Q.O.S. for passenger load factor.

Table 2: Quality of Service for Passenger Load

\begin{tabular}{lllllll}
\hline Q.O.S & A & B & C & D & E & F \\
\hline \multirow{4}{*}{ Load } & More & More & More & More & More & More \\
Fac- & than & than & than & Than & Than & Than \\
tor & seated & $50 \%$ & $50 \%$ & $50 \%$ & $50 \%$ & $50 \%$ \\
& load & load & seated & seated & seated & seated \\
& & & load & load & load & load \\
\hline
\end{tabular}

\subsection{Comparison car and bus travel time}

Travel time is measurement of different between bus (transit facilities) and car (automobile travel). Travel time for bus and car was compare and it's not include waiting time. For car, it include time to park and to walk to destination.

This procedure was followed the method used in the Transit Capacity and Quality of Service Manual[6]. The time for daily peak hour were:-

Morning-Peak : 7.30morning - 9.30morning, af-ternoo-Peak : 12.00afternoon -2.00 afternoon, evening-Peak : 4.30evening -6.30 Evening.

The time from initial point to end point was recorded for both bus and car. Ratio between bus travel time (transit time) and car travel time (auto vehicles time) was calculated and will be check in table 3 to determine the Q.O.S.

Table 3: Quality of Service for Comparison Car and Bus Travel Time

\begin{tabular}{lllllll}
\hline Q.O.S. & $\mathrm{A}$ & $\mathrm{B}$ & $\mathrm{C}$ & $\mathrm{D}$ & $\mathrm{E}$ & $\mathrm{F}$ \\
\hline Comparison Car and & & $>1$ & $>1.25$ & $>1.5$ & $>1.75$ to & \\
Bus Travel Time Ra- & 1 & to & to 1.5 & to & 2.0 & \\
tio & & 1.25 & & 1.75 & & \\
\hline
\end{tabular}

\subsection{Service frequency}

According to the Q.O.S. Method of the Transit Capacity and Quality of Service Manual (3rd Edition),[5][7][8] Service frequency, from user's perspective, it how many times an hour a user can access to transit facilities Determination of service frequency LOS will be by destination from a given transit stop, as some route might serve a given stop. By date get from bus provider the services frequency head to head bus was check and compare in table 2.6 .

Table 4: Services Frequency

\begin{tabular}{lllllll}
\hline $\begin{array}{l}\text { Quality Of Ser- } \\
\text { vice }\end{array}$ & A & B & C & D & E & F \\
\hline $\begin{array}{l}\text { Average head- } \\
\text { way (min) }\end{array}$ & $<=5$ & $>5-10$ & $11-15$ & $16-30$ & $31-59$ & $>60$ \\
\hline
\end{tabular}

\subsection{On time performance}

On time performance measures the degree of bus arrive at the schedule times [12] [13]. The measurement will be conducted at selected locations for time sensitive trips such as office, school, shopping area and others important area [9] [10]. On time performance usually to measure the bus do not arrive late. In the other hand,

If the bus come early its can cause the problem since rider can't catch up the bus on time as schedule[15]. The users may feel uncomfortable to hurry outside to meet the early arrival time. In certain cases, early arrival may also results no-shows of passengers. The Q.O.S was checked by compare the percentage value with those in Table 5.

Table 5: Q.O.S for On-Time Performance

\begin{tabular}{llllll}
\multicolumn{5}{c}{} \\
\hline Q.O.S & $\mathrm{A}$ & $\mathrm{B}$ & $\mathrm{C}$ & $\mathrm{D}$ & $\mathrm{E}$ \\
\hline On time per- & $95 \%-$ & $90 \%-$ & $80 \%-$ & $70 \%-$ & \multirow{2}{*}{ f } \\
formance & $100 \%$ & $94 \%$ & $89 \%$ & $79 \%$ & \\
\hline
\end{tabular}

\subsection{Services coverage}

There will be a main key factor for users to use the transit in presence or absence transit service in near of origin and destination area[16]. Service coverage area will consider both ends of the trip. As the example is the home and work destination. Most of pedestrian only can walk maximum $400 \mathrm{~m}$ from their origin to nearest transit. In order to know the coverage area, $400 \mathrm{~m}$ from all routes should be identified. The total coverage area was later compared in Table 6 below:

Table 6: Service Coverage Quality of Service

\begin{tabular}{lll}
\hline Q.O.S & $\begin{array}{l}\text { Coverage Area Per- } \\
\text { centage }(\%)\end{array}$ & Comment \\
\hline A & 90.00 to 100.00 & $\begin{array}{l}\text { Virtually major origins and desti- } \\
\text { nation served } \\
\text { Most major origins and destina- } \\
\text { tions served } \\
\text { Bbout } 3 / 4 \text { of higher density areas } \\
\text { served }\end{array}$ \\
C & 70.00 to 79.90 & $\begin{array}{l}\text { About two-thirds of higher den- } \\
\text { sity areas served } \\
\text { At least } 1 / 2 \text { of the higher density } \\
\text { areas served } \\
\text { Less than } 1 / 2 \text { of higher density ar- } \\
\text { eas served }\end{array}$ \\
\hline
\end{tabular}

\section{Results}

\subsection{Service hour}

From bus schedule for Route 200, Route 500, Route 800, Route 900 and Route 901 respectively, hours of services was recorded. Hours of services was counted from first trip of the services until last trip of that day. Table 7, shows quality of service for hours of services for all routes

Table 7: Quality of Service for Hours of Services

\begin{tabular}{lllll}
\multicolumn{7}{c}{ Table 7: Quality of Service for Hours of Services } \\
\hline Route & First Trip & Last Trip & Hours of Services & Q.O.S. \\
\hline 200 & $6.30 \mathrm{am}$ & $11.50 \mathrm{pm}$ & 17 hours $20 \mathrm{~min}$ & B \\
500 & $6.30 \mathrm{am}$ & $11.30 \mathrm{pm}$ & 17 hours & B \\
800 & $6.30 \mathrm{am}$ & $11.00 \mathrm{pm}$ & 16 hours $30 \mathrm{~min}$ & B \\
900 & $6.30 \mathrm{am}$ & $11.00 \mathrm{pm}$ & 16 hours $30 \mathrm{~min}$ & B \\
901 & $6.30 \mathrm{am}$ & $11.00 \mathrm{pm}$ & 16 hours $30 \mathrm{~min}$ & B \\
& & & Average & B \\
\hline
\end{tabular}

\subsection{Passenger load}

To calculated passenger load factor, numbers of passenger seating on the bus was divided by numbers of seats in the bus. This passenger The data collection was done in 4 different time frame which are Peak Hours Morning (7am-9am), Non Peak Hours Day (11am2pm), Peak Hours Evening (4pm-7pm) and Non Peak Hours Night (8pm-10pm). Table 8 shows Load Factor Summary for Putrajaya Bus. The data for return route also recorded. Finally average passenger load factor was translate to percentage to analyze the quality of services.

Table 8: Passenger Load Factor Summary for Putrajaya Bus

\begin{tabular}{lcccccc}
\hline Route & 200 & 500 & 800 & 900 & 901 & $\begin{array}{l}\text { Aver- } \\
\text { age }\end{array}$ \\
\hline $\begin{array}{l}\text { Peak Hours } \\
\text { Morning } \\
\text { (weekday) }\end{array}$ & 0.13 & 0.08 & 0.00 & 0.00 & 0.00 & 0.04 \\
$\begin{array}{l}\text { Non Peak } \\
\text { Hours Day } \\
\text { (weekday) }\end{array}$ & 0.06 & 0.01 & 0.01 & 0.02 & 0.00 & 0.02 \\
$\begin{array}{l}\text { Peak Hours } \\
\text { Evening } \\
\text { (weekday) }\end{array}$ & 0.03 & 0.01 & 0.08 & 0.00 & 0.01 & 0.03 \\
$\begin{array}{l}\text { Non Peak } \\
\text { Hours Night } \\
\text { (weekday) }\end{array}$ & 0.00 & 0.01 & 0.00 & 0.00 & 0.00 & 0.00 \\
$\begin{array}{l}\text { Peak Hours } \\
\text { Morning } \\
\text { (weekend) }\end{array}$ & 0.08 & 0.07 & 0.00 & $\mathrm{n} / \mathrm{a}$ & $\mathrm{n} / \mathrm{a}$ & 0.05 \\
\hline
\end{tabular}




\begin{tabular}{lccc|ccc}
\hline $\begin{array}{l}\text { Non Peak } \\
\text { Hours Day } \\
\text { (weekend) }\end{array}$ & 0.18 & 0.08 & 0.00 & $\mathrm{n} / \mathrm{a}$ & $\mathrm{n} / \mathrm{a}$ & 0.09 \\
$\begin{array}{l}\text { Peak Hours } \\
\text { Evening } \\
\text { (weekend) }\end{array}$ & 0.00 & 0.00 & 0.00 & $\mathrm{n} / \mathrm{a}$ & $\mathrm{n} / \mathrm{a}$ & 0.00 \\
$\begin{array}{l}\text { Non Peak } \\
\begin{array}{l}\text { Hours Night } \\
\text { (weekend) }\end{array}\end{array}$ & 0.08 & 0.01 & 0.00 & $\mathrm{n} / \mathrm{a}$ & $\mathrm{n} / \mathrm{a}$ & 0.03 \\
$\begin{array}{l}\text { Average } \\
\text { (weekday) }\end{array}$ & 0.06 & 0.03 & 0.02 & 0.01 & 0.0025 & 0.02 \\
\hline
\end{tabular}

\begin{tabular}{lllllll}
\hline $\begin{array}{l}\text { Average } \\
\text { (weekend) }\end{array}$ & 0.09 & 0.04 & 0.00 & $\mathrm{n} / \mathrm{a}$ & $\mathrm{n} / \mathrm{a}$ & 0.04 \\
Average & 0.07 & 0.03 & 0.01 & 0.01 & 0.0025 & 0.02 \\
Q.O.S & $\mathrm{A}$ & $\mathrm{A}$ & $\mathrm{A}$ & $\mathrm{A}$ & $\mathrm{A}$ & $\mathrm{A}$ \\
\hline
\end{tabular}

\subsection{Transit auto travel time}

A comparison of both route by bus and by car were recorded. The journey both away and return were recorded for each stop. The ratio was analysed and the results tabulated in table 9 .

Table 9: Summary for Transit Auto Travel Time

\begin{tabular}{|c|c|c|c|c|c|c|c|c|c|c|c|c|c|c|}
\hline \multirow{2}{*}{ Route } & \multicolumn{3}{|c|}{ Peak hours morning } & \multicolumn{3}{|c|}{ Non peak 5hours day } & \multicolumn{3}{|c|}{ Peak hours evening } & \multicolumn{3}{|c|}{ Non peak hours night } & \multirow{2}{*}{$\begin{array}{l}\text { Aver- } \\
\text { age }\end{array}$} & \multirow{2}{*}{ QOS } \\
\hline & bus & car & ratio & bus & car & ratio & bus & car & ratio & bus & car & ratio & & \\
\hline 200 & 74 & 97 & 0.8 & 53 & 51 & 1.0 & 59 & 53 & 1.1 & 42 & 38 & 1.1 & 1.0 & A \\
\hline 500 & 46 & 33 & 1.4 & 39 & 34 & 1.1 & 51 & 37 & 1.4 & 49 & 33 & 1.5 & 1.4 & $\mathrm{C}$ \\
\hline 800 & 38 & 46 & 0.8 & 39 & 28 & 1.4 & 26 & 31 & 0.8 & 31 & 25 & 1.2 & 1.1 & $\mathrm{~B}$ \\
\hline 900 & 12 & 30 & 0.4 & 14 & 10 & 1.4 & 16 & 17 & 0.9 & 18 & 9 & 2.0 & 1.2 & B \\
\hline 901 & 40 & 80 & 0.5 & 39 & 37 & 1.1 & 37 & 40 & 0.9 & 36 & 34 & 1.1 & 0.9 & $\begin{array}{l}\text { A } \\
\text { B }\end{array}$ \\
\hline
\end{tabular}

\subsection{Punctuality performance}

The time arrival and time in schedule was compared to get the on time arrival or late arrival [1]. Table 10 shows the Punctuality performance percentage details for all routes. As the results only route 900 achieve LOS B and others either LOS E or G.

Table 10: Punctuality Performance for Both Routes

\begin{tabular}{|c|c|c|c|c|c|}
\hline Route & Day & $\begin{array}{l}\text { Total } \\
\text { Actual } \\
\text { Arrivals } \\
\end{array}$ & $\begin{array}{l}\text { No of } \\
\text { punctual } \\
\text { Arrivals }\end{array}$ & $\begin{array}{l}\text { Punctuality } \\
\text { Percentage }\end{array}$ & $\begin{array}{l}\text { Quality } \\
\text { of Ser- } \\
\text { vice }\end{array}$ \\
\hline \multirow[t]{2}{*}{200} & $\begin{array}{l}\text { Week- } \\
\text { day }\end{array}$ & 51 & 16 & $31.37 \%$ & $\mathrm{~F}$ \\
\hline & $\begin{array}{l}\text { Week- } \\
\text { end }\end{array}$ & 38 & 19 & $50.00 \%$ & F \\
\hline \multirow[t]{2}{*}{500} & $\begin{array}{l}\text { Week- } \\
\text { day }\end{array}$ & 45 & 34 & $75.56 \%$ & E \\
\hline & $\begin{array}{l}\text { Week- } \\
\text { end }\end{array}$ & 46 & 36 & $78.26 \%$ & E \\
\hline \multirow[t]{2}{*}{800} & $\begin{array}{l}\text { Week- } \\
\text { day }\end{array}$ & 43 & 21 & $48.84 \%$ & $\mathrm{~F}$ \\
\hline & $\begin{array}{l}\text { Week- } \\
\text { end }\end{array}$ & 41 & 15 & $36.59 \%$ & $\mathrm{~F}$ \\
\hline 900 & $\begin{array}{l}\text { Week- } \\
\text { day }\end{array}$ & 96 & 87 & $90.63 \%$ & B \\
\hline \multirow[t]{2}{*}{901} & $\begin{array}{l}\text { Week- } \\
\text { day }\end{array}$ & 41 & 15 & $36.59 \%$ & $\mathrm{~F}$ \\
\hline & & & Average & & $\mathrm{F}$ \\
\hline
\end{tabular}

\subsection{Service frequency}

As from bus schedule for Route 200, Route 500, Route 800, Route 900 and Route 901 respectively, numbers of intervals have been determined according to minutes per intervals. Table 4.24 shows the numbers of intervals in all routes for respective minute's interval. The level of services for services frequency was check using Fixed Route Services Frequency LOS. Tables 3.5 give results for services frequency LOS for every route.

Table 11: Service Frequencies for Route in Putrajaya

\begin{tabular}{lllllllll}
\multicolumn{8}{c}{ Table 11: Service Frequencies for Route in Putrajaya } \\
\hline Route & $\begin{array}{l}40 \\
\min \end{array}$ & $\begin{array}{l}30 \\
\min \end{array}$ & $\begin{array}{l}25 \\
\min \end{array}$ & $\begin{array}{l}20 \\
\min \end{array}$ & $\begin{array}{l}15 \\
\min \end{array}$ & $\begin{array}{l}10 \\
\text { min }\end{array}$ & $\begin{array}{l}\text { Aver- } \\
\text { age in- } \\
\text { terval }\end{array}$ & Q.O.S \\
\hline 200 & & & 1 & 39 & 15 & & 18.72 & $\mathrm{C}$ \\
500 & & 34 & & & & & 30 & $\mathrm{D}$ \\
800 & 3 & 13 & & 25 & & & 24.63 & $\mathrm{D}$ \\
900 & & 1 & & 28 & 39 & 24 & 13.36 & $\mathrm{~B}$ \\
901 & & 2 & & 28 & & $\begin{array}{l}18.7 \\
\text { Aver- } \\
\text { age }\end{array}$ & $\mathrm{C}$ \\
\hline
\end{tabular}

\subsection{Service coverage}

Services coverage area method identified the percentage of bus coverage area in case study area. Figure 3.6 shows the overall all routes coverage area within $400 \mathrm{~m}$ from the road and also show the divided box to identify the percentage of coverage area. From map for bus route for Route 200 , bus route for Route 500, bus route for Route 800 , bus route for Route 900 , bus route for Route

901, bus route for all routes respectively. The operating bus service coverage in Putrajaya was determined and summarized in the Table 12 below.

Table 12: Coverage Area (Services) in Percentage

\begin{tabular}{llllllllllll}
\hline & 0 & 10 & 20 & 30 & 40 & 50 & 60 & 70 & 80 & 90 & 10 \\
$\%$ & $\%$ & $\%$ & $\%$ & $\%$ & $\%$ & $\%$ & $\%$ & $\%$ & $\%$ & $0 \%$ \\
\hline $\mathrm{N}$ & 3 & 7 & 5 & 2 & 3 & 4 & 4 & 8 & 7 & 0 & 1 \\
\hline
\end{tabular}

Total Coverage Area $=[(0 \% \mathrm{X} 35)+(10 \% \mathrm{X} 7)+(20 \% \mathrm{X} 5)+(30 \% \mathrm{X} 2)+$ $(40 \% \mathrm{X} 3)+(50 \% \mathrm{X} 4)+(60 \% \mathrm{X} 4)+(70 \% \mathrm{X} 8)+(80 \% \mathrm{X} 7)+(90 \% \mathrm{X} 0)+$ $(100 \% \mathrm{X} 1)]=25.65 \%$

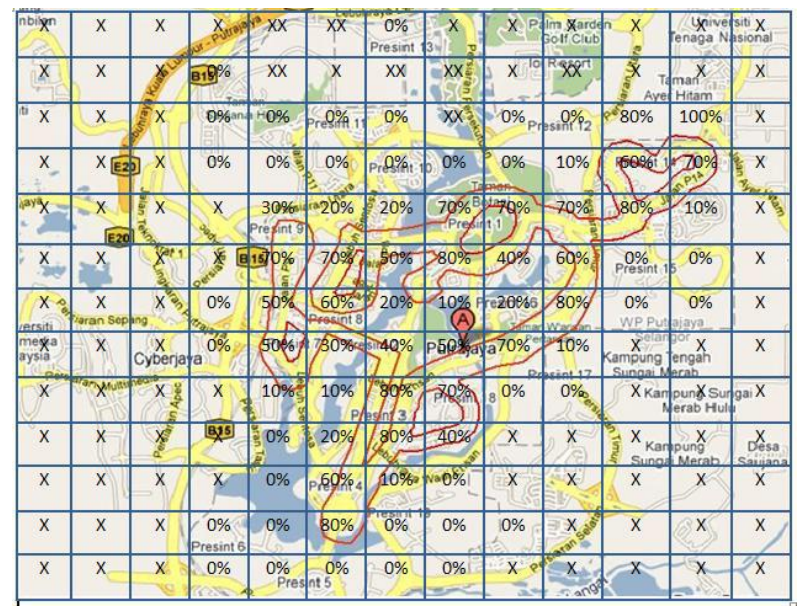

Fig. 1: Service Coverage Area in Putrajaya.

Average score QOS performance summary for bus in Kajang The average score were analyzed accordingly follow by method given before [3]. 
Table 13: Q.O.S Score vs. Q.O.S. Attributes

\begin{tabular}{lllll}
\hline \multicolumn{4}{c}{ Table 13: Q.O.S Score vs. Q.O.S. Attributes } \\
\hline Attributes & QOS & $\begin{array}{l}\text { QOS } \\
\text { Score }\end{array}$ & $\begin{array}{l}\text { Mean } \\
\text { QOS }\end{array}$ & $\begin{array}{l}\text { Final Overall } \\
\text { QOS }\end{array}$ \\
\hline $\begin{array}{l}\text { Hours of Service } \\
\text { Load Factor (Pas- }\end{array}$ & B & 5 & & \\
senger) & B & 5 & & \\
$\begin{array}{l}\text { Frequency of Bus } \\
\text { Compare Auto }\end{array}$ & D & 3 & & \\
Travel Time & B & 5 & & \\
Coverage Area & F & 1 & 3.5 & D \\
Punctuality & E & 2 & & \\
Total & & 21 & & \\
\hline
\end{tabular}

\section{Conclusion}

This research paper was done to evaluate bus performance in area of Putrajaya, Malaysia. This research was done by using rating for services quality.

Putrajaya is a major route connected to Cyberjaya, Puchong, Dengkil, Serdang and Bandar Baru Bangi. It is recommended this connected route to review as well for quality services for bus.

Outcomes of this case study, three attribute should be improve which is coverage area, services frequency, and on time performance.

Others attribute; passenger load, services hours, and comparison of ratio car and bus are good and no need to be changed.

As conclusion, in Putrajaya, the quality services for bus is $\mathrm{C}$, which is moderate and need improvement.

\section{Acknowledgement}

Authors would liketo thanks Institute of Infrastructure Energy, Universiti Tenaga Nasional for use of services and facilities and Universiti Tenaga Nasional for BOLD UNIG Grant J510050718.

\section{References}

[1] Chang, S.K.J. and Hsu, C.L., Modeling Passenger Wait-ing Time for Intermodal Transit Stations, Journal of Transportation Research Board No. 1753, pp.69-75, 2001. https://doi.org/10.3141/1753-09.

[2] Amiril, A., Nawawi, A. H., Takim, R., \& Latif, S. N. F. A. (2014) Transportation Infrastructure Project Sustainability Factors and Performance. Procedia - Social and Behavioral Sciences, 153, 90-98. https://doi.org/10.1016/i.sbspro.2014.10.044.

[3] Bachok, S., Osman, M. M., \& Ponrahono, Z. (2014). Passenger's Aspiration Towards Sustainable Public Transportation System: Kerian District, Perak, Malaysia. Procedia - Social and Behavioral Sciences, 153, 553-565. https://doi.org/10.1016/j.sbspro.2014.10.088.

[4] Department of Statistics, M. (2011). Population and Housing Census of Malaysia 2010. Department of Statistics, Malaysia, 77.

[5] Eboli, L., Forciniti, C., \& Mazzulla, G. (2014). Service Coverage Factors Affecting Bus Transit System Availability. Procedia - Social and Behavioral Sciences, 111, 984-993. https://doi.org/10.1016/i.sbspro.2014.01.133.

[6] Lee, D. A., Watson, C. H. L. S., Central, L., Regional, F., Authority, T., Hair, V. I. C. E. C., Wilson, F. (2007). COOPERATIVE. Washington DC, USA.

[7] Piriyawat, C., Candidate, D., \& Author, P. (n.d.). Alternative Methods for Investigating Bus Service Quality and User Dissatisfaction in Bangkok and Its Vicinity Alternative Methods for Investigating Bus Service Quality and User Dissatisfaction in Bangkok and Its Vicinity.

[8] Redman, L., Friman, M., Gärling, T., \& Hartig, T. (2013). Quality attributes of public transport that attract car users: A research review. Transport Policy, 25, 119-127. https://doi.org/10.1016/j.tranpol.2012.11.005

[9] Rohani, M. M., Wijeyesekera, D. C., \& Karim, A. T. A. (2013). Bus operation, quality service and the role of bus provider and driver. Procedia Engineering, 53, 167-178. https://doi.org/10.1016/j.proeng.2013.02.022.

[10] Sabra, W. and A. (2003). A Comparison between Highway Capacity Manual and Critical Lane Volume Analysis Methodologies for Traffic Impact Study Applications, 1-7.

[11] Shariff, N. M. (2012). Private Vehicle Ownership and Transportation Planning in Malaysia. In International Conference On Traffic And Transportation Engineering (Vol. 26, pp. 64-68).
[12] Suwardo, Napiah, M. B., \& Ibrahim B. Kamaruddin. (2009). OnTime Performance and Service Regularity of Stage Buses in Mixed Traffic. World Academy of Science, Engineering and Technology, 3(7), 1137-1144

[13] Suwardo, W., Napiah, M., \& Kamaruddin, I. (2008). Punctuality and Expected Waiting Time of Stage Buses in Mixed Traffic. Jurnal Transportasi, 8(3), 213-226. Retrieved from htt

[14] Transportation Research Board (TRB) (1999). A Handbook for Measuring Customer Satisfaction and Service Quality. TCRP Report 47

[15] Yaakub, N., \& Napiah, M. (2011). Public Transport: Punctuality Index for Bus Operation, World Academy of Science. Engineering and Technology, 60(12), 12-23.

[16] Hazril, M. I., Sabri, S. M. I. \& Tajedi, N. A. A. (2013). A study on previous and ongoing research regarding public transportation in Malaysia. Proc. Malaysian Technical Universities Conference on Engineering \& Technology (MUCET), Kuantan, Pahang, Malaysia, 3-4 December. 